\title{
PENGARUH CITRA KOPERASI TERHADAP LOYALITAS ANGGOTA KOPERASI PADA KOPERASI SIMPAN PINJAM (KSP) JASA DI KABUPATEN KENDAL
}

\author{
Th Susetyarsi \\ Prodi Manajemen STIE SEMARANG
}

\begin{abstract}
The purpose of this research is to analyze the effect of cooperative image consisting of values and principles and member transactions on the loyalty of cooperative members at KSP Services in Kendal Regency.

In this study the population of 3,234 people, the sample used as many as 100 people. The method of analysis using multiple regression, coefficient of determination and t test and F test with the help of SPSS in the calculation.

The results of this study indicate that the image of cooperatives consisting of values and principles and member transactions on the loyalty of members of the cooperative in KSP Services in Kendal Regency have a positive influence.
\end{abstract}

Keywords: Loyalty, cooperative image.

\begin{abstract}
ABSTRAK
Tujuan diadakannya penelitian ini adalah untuk menganalisis pengaruh citra koperasi yang terdiri dari nilai dan prinsip serta transaksi anggota terhadap loyalitas anggota koperasi pada KSP Jasa di Kabupaten Kendal.

Dalam penelitian ini populasi sebanyak 3.234 orang, sampel digunakan sebanyak 100 orang. Metode analisis menggunakan regresi berganda, koefisien determinasi beserta uji t dan uji F dengan bantuan SPSS dalam perhitungannya.

Hasil penelitian ini menunjukkan bahwa citra koperasi yang terdiri dari nilai dan prinsip dan transaksi anggota terhadap loyalitas anggota koperasi pada KSP Jasa di Kabupaten Kendal mempunyai pengaruh yang positif.
\end{abstract}

Kata kunci : Loyalitas, citra koperasi.

\section{Pendahuluan}

Citra adalah kesan yang diperoleh melalui pengetahuan dan pengalaman seseorang tentang suatu hal. Bagi perusahaan citra diartikan sebagai persepsi konsumen terhadap jati diri perusahaan. Persepsi konsumen terhadap perusahaan didasari pada apa yang mereka ketahui atau mereka kira tentang perusahaan yang 
bersangkutan. Citra perusahaan yang baik dimaksudkan agar perusahaan dapat tetaphidup dan meningkatkan kreativitasnya bahkan memberikan manfaat lebih bagi orang lain.

Citra merupakan tujuan dan sekaligus merupakan reputasi dan prestasi yang hendak dicapai. Walaupun citra merupakan sesuatu yang abstrak dan tidak dapat diukur secara sistematis, namun wujudnya dapat dirasakan. Penilaian atau tanggapan tersebut dapat berkaitan dengan timbulnya rasa hormat (respect), kesan-kesan yang baik yang berakar pada nilai-nilai kepercayaan.

Keinginan sebuah organisasi untuk mempunyai citra yang baik pada konsumen sasaran berawal dari pengertian yang tepat mengenai citra sebagai stimulus adanya pengelolaan upaya yang perlu dilaksanakan. Ketepatan pengertian citra agar organisasi dapat menetapkan upaya dalam mewujudkannya pada obyek dan mendorong prioritas pelaksanaan. Citra menampilkan kesan suatu obyek terhadap obyek yang lain yang terbentuk dengan memproses informasi setiap waktu dari berbagai sumber terpercaya.

Pentingnya citra sebuah perusahaan dikarenakan citra positif dapat memberikan kemudahan bagi perusahaan untuk berkomunikasi dan mencapai tujuan secara efektif, sedangkan citra negatif sebaliknya. Citra positif dapat digunakan sebagai pelindung terhadap kesalahan kecil, kualitas teknis atau fungsional sedangkan citra negatif dapat memperbesar kesalahan tersebut. Citra menggambarkan pengalaman dan harapan konsumen atas kualitas pelayanan perusahaan dan citra mempunyai pengaruh penting terhadap manajemen atau dampak internal, dimana citra perusahaan yang kurang jelas dan nyata dapat mempengaruhi sikap karyawan pelaksanaan.

Citra baik merupakan harta yang sangat tinggi nilainya bagi perusahaan manapun. Citra mendukung daya saing perusahaan dalam jangka menengah dan panjang. Citra baik dapat menjadi perisai perusahaan saat berada dalam masa krisis. Oleh karena itu, setiap perusahaan mempunyai kewajiban untuk membangun citra baik perusahaan. Citra pada suatu perusahaan akan menampilkan gambaran yang baik yang ada di dalam benak konsumen mengenai suatu perusahaan terhadap 
perusahaan yang lain, yang terbentuk dengan memproses informasi setiap waktu dari berbagai sumber terpercaya.

Lebih lanjut, keberhasilan perusahaan membangun citra yang baik akan mampu mewujudkan loyalitas pelanggan. Federico (2003) mengatakan loyalitas konsumen adalah kondisi dimana konsumen mempunyai sifat positif terhadap sebuah perusahaan, mempunyai komitmen terhadap perusahaan tersebut, dan bermaksud meneruskan pembelian dimasa mendatang. Terjadinya loyalitas pada konsumen disebabkan oleh adanya pengaruh kepuasan/ketidakpuasan dengan perusahaan tersebut, yang terakumulasi secara terus-menerus disamping adanya presepsi tentang kualitas produk. Oleh karena itu, saat ini pembentukan citra baik yang ada di dalam benak konsumen terhadap suatu perusahaan menjadi perhatian utama.

Masalah citra perusahaan yang baik agar dapat diperoleh loyalitas pelanggan juga sangat diperhatikan oleh koperasi simpan pinjam (KSP) Jasa di Kabupaten Kendal. Sebagai salah satu koperasi yang bergerak di bidang keuangan, khususnya simpan pinjam maka citra koperasi yang baik menjadi hal penting bagi koperasi yang bersangkutan. Mengingat saat ini persaingan di bisnis keuangan sudah sangat ketat, dengan semakin banyaknya pelaku usaha di bidang ini seperti perbankan, bank perkreditan rakyat, bank-bank syariah, pegadaian termasuk sesama koperasi simpan pinjam yang ada di tanah air.

Berbagai macam dan cara telah dilakukan oleh KSP Jasa di Kabupaten Kendal agar loyalitas anggota koperasi tetap terjaga dan dan bila perlu meningkat, salah satunya melalui perbaikan dan peningkatan citra baik koperasi melalui pelaksanaan nilai dan prinsip koperasi secara baik dan benar. Selain itu tidak kalah pentingnya adalah memberikan kepuasan pada para anggota koperasi pada saat melakukan transaksi pada KSP Jasa di Kabupaten Kendal. Transaksi anggota ini terutama dipengaruhi oleh sistem, prosedur dan pelayanan yang ada pada KSP Jasa di Kabupaten Kendal. Dengan transaksi anggota berupa sistem, prosedur dan pelayanan yang baik maka loyalitas anggota akan meningkat.

Nilai koperasi adalah nilai kesamaan, kekeluargaan, mandiri, peduli terhadap sesama dan kemandirian salah satunya. Koperasi Indonesia berangkat 
dari nilai koletivisme yang tercermin dengan budaya gotong royong. Nilai yang mendasari kegiatan koperasi yang dipakai pada penelitian ini berupa kekeluargaan dan bertanggung jawab Sedangkan nilai yang diyakini anggota koperasi yang dipakai pada penelitian ini berupa kejujuran dan kepedulian terhadap orang lain.

Prinsip koperasi adalah garis-garis penuntun yang digunakan oleh koperasi untuk melaksanakan nilai-nilai tersebut dalam praktik. Prinsip koperasi ini menjadi sumber inspirasi dan menjiwai secara keseluruhan organisasi dan kegiatan usaha koperasi sesuai dengan maksud dan tujuan pendiriannya. Pada penelitian ini mempergunakan prinsip koperasi berupa keanggotaan koperasi bersifat sukarela dan terbuka serta koperasi melayani anggotanya secara prima.

Selain itu penerapan transaksi anggota dengan sistem, prosedur dan pelayanan yang baik akan mampu meningkatkan loyalitas anggota pada KSP Jasa di Kabupaten Kendal. Sistem merupakan suatu jaringan transaksi yang dibuat menurut pola yang terpadu untuk melaksanakan kegiatan pokok organisasi dalam hal ini koperasi. Pada KSP Jasa diterapkan sistem transaksi yang cepat dan tepat dibantu pemakaian komputer. Prosedur adalah suatu urutan kegiatan klerikal, biasanya melibatkan beberapa orang dalam satu departemen atau lebih, yang dibuat untuk menjamin penanganan secara seragam transaksi organisasi yang terjadi berulang-ulang. Pada KSP Jasa di Kabupaten dibuat prosedur yang mudah dan tidak berbelit-belit.

Berkaitan dengan pelayanan, pelayanan merupakan faktor ketiga dari transaksi anggota yang sangat penting bagi KSP Jasa di Kabupaten Kendal untuk dapat memberikan kepuasan kepada para anggotanya. Selain itu pelayanan merupakan suatu cara agar anggota tertarik terhadap kinerja suatu koperasi. Kualitas pelayanan yang lebih baik dapat untuk mempertahankan loyalitas anggota koperasi. 


\section{Masalah Penelitian}

Berdasarkan latar belakang di atas maka rumusan masalah yang hendak dikaji yaitu :

1. Apakah ada pengaruh citra koperasi berupa nilai dan prinsip koperasi terhadap loyalitas anggota koperasi pada KSP Jasa di Kabupaten Kendal.

2. Apakah ada pengaruh citra koperasi berupa transaksi anggota terhadap loyalitas anggota koperasi pada KSP Jasa di Kabupaten Kendal.

\section{Kajian Teoritis}

\section{Koperasi}

Koperasi adalah gerakan yang terorganisasi yang didorong oleh cita - cita rakyat mencapai masyarakat yang maju, adil dan makmur seperti yang diamanatkan oleh UUD 1945 khususnya pasal 33 ayat (1) yang menyatakan bahwa:

"Perekonomian disusun sebagai usaha bersama berdasar atas asas kekeluargaan". Dan "bangun perusahaan yang sesuai dengan itu ialah koperasi". Karena dorongan cita - cita rakyat itu, undang - undang tentang perkoperasian No. 25 Tahun 1992 menyatakan bahwa koperasi selain badan usaha juga adalah gerakan ekonomi rakyat.

Sebagai gerakan ekonomi rakyat, koperasi bukan hanya milik orang kaya melainkan juga milik oleh seluruh rakyat Indonesia tanpa terkecuali.

Berikut ini adalah landasan koperasi Indonesia yang melandasi aktifitas koperasi di Indonesia.

- $\quad$ Landasan Idiil ( Pancasila )

- Landasan Mental ( Setia kawan dan kesadaran diri sendiri )

- Landasan Struktural dan gerak ( UUD 1945 Pasal 33 Ayat 1 )

Definisi Koperasi Menurut Undang - Undang No. 25 Tahun 1992

Undang - undang No. 25 tahun 1992, memberikan definisi "Koperasi adalah badan usaha yang beranggotakan orang - orang atau badan hukum 
koperasi yang melandaskan kegiatannya berdasarkan prinsip koperasi sekaligus sebagai gerakan ekonomi rakyat yang berdasar atas asas kekeluargaan”.

Berdasarkan batasan koperasi, koperasi Indonesia mengandung 5 unsur sebagai berikut :

- $\quad$ Koperasi adalah badan usaha (Business Enterprise)

- Koperasi adalah kumpulan orang - orang dan atau badan - badan hokum koperasi

- Koperasi Indonesia adalah koperasi yang bekerja berdasarkan “prinsip prinsip koperasi"

- Koperasi Indonesia adalah "Gerakan Ekonomi Rakyat".

Koperasi Indonesia "berazaskan kekeluargaan"

Adapun tujuan utama koperasi adalah mewujudkan masyarakat adil makmur material dan spiritual berdasarkan Pancasila dan Undang - Undang Dasar 1945.

Dalam BAB II Pasal 3 Undang - undang RI No. 25 Tahun 1992, menyatakan bahwa koperasi bertujuan untuk:

"Memajukan kesejahteraan anggota pada khususnya dan masyarakat pada umumnya serta ikut membangun tatanan perekonomian nasional dalam rangka mewujudkan masyarakat yang maju, adil dan makmur berlandaskan Pancasila dan Undang - undang Dasar 1945”.

Menurut Bang Hatta, tujuan koperasi bukanlah mencari laba yang sebesarbesarnya, melainkan melayani kebutuhan bersama dan wadah partisipasi pelaku ekonomi skala kecil.

Selanjutnya fungsi koperasi tertuang dalam pasal 4 UU No. 25 Tahun 1992 tentang perkoperasian, yaitu:

- Membangun dan mengembangkan potensi dan kemampuan ekonomi anggota pada khususnya dan masyarakat pada umumnya untuk meningkatkan kesejahteraan ekonomi dan sosialnya.

- Berperan serta aktif dalam upaya mempertinggi kualitas kehidupan manusia dan masyarakat.

- Memperkokoh perekonomian rakyat sebagai dasar kekuatan dan ketahanan perekonomian nasional dengan koperasi sebagai gurunya. 
- Berusaha untuk mewujudkan dan mengembangkan perekonomian nasional yang merupakan usaha bersama berdasar atas azas kekeluargaan dan demokrasi ekonomi.

Seperti halnya perusahaan koperasi juga tidak luput dengan adanya citra. Pencitraan seperti apa sangat tergantung dari keberadaan koperasi itu sendiri. Citra koperasi atau perusahaan penting bagi setiap koperasi atau perusahaan karena merupakan keseluruhan kesan yang terbentuk dibenak masyarakat tentang koperasi atau perusahaan. Citra dapat berhubungan dengan nama bisnis, arsitektur, variasi dari produk, tradisi, ideologi dan kesan pada kualitas komunikasi yang dilakukan oleh setiap karyawan yang berinteraksi dengan klien perusahaan (Kartajaya, 1996).

Dengan demikian, citra koperasi atau perusahaan dapat dipersepsikan sebagai gambaran mental secara selektif. Karena keseluruhan kesan tentang karakteristik suatu koperasi atau perusahaan-lah yang nantinya akan membentuk citra koperasi atau perusahaan dibenak masyarakat. Setiap koperasi atau perusahaan dapat memiliki lebih dari satu citra tergantung dari kondisi interaksi yang dilakukan koperasi atau perusahaan dengan kelompok-kelompok yang berbeda, seperti: nasabah, karyawan, pemegang saham, supplier dimana setiap kelompok tersebut mempunyai pengalaman dan hubungan yang berbeda dengan perusahaan. Karena itu, citra yang dimiliki koperasi atau perusahaan dapat berperingkat positif atau negatif.

Untuk itu, koperasi atau perusahaan perlu mengkomunikasikan secara jelas tentang koperasi atau perusahaan yang diharapkan, sehingga dapat mengarahkan masyarakat dalam mencitrakan koperasi atau perusahaan secara positif. Lebih lanjut, citra merupakan hasil dari penilaian atas sejumlah atribut, tetapi citra bukanlah penilaian itu sendiri, karena citra adalah kesan konsumen yang paling menonjol dari koperasi atau perusahaan, yang dievaluasi dan dipertimbangkan oleh anggota dan konsumen dalam mengambil keputusan pembelian. 
Mowen (2002) menyatakan bahwa perusahaan yang fokus terhadap core businessnya akan lebih sukses. Hal tersebut merefleksikan core competencies yang dipunyai perusahaan. Perusahaan yang mempunyai reputasi positif lebih memungkinkan untuk menarik minat pelamar berkualitas tinggi, membangun pangsa pasar yang luas, menerapkan harga yang tinggi dan lebih menarik minat investor. Dengan kata lain, citra perusahaan yang baik memberikan perusahaan keunggulan kompetitif.

Lebih lanjut, keberhasilan perusahaan membangun citra yang baik akan mampu mewujudkan loyalitas pelanggan. Federico (2003) mengatakan loyalitas konsumen adalah kondisi dimana konsumen mempunyai sifat positif terhadap sebuah perusahaan, mempunyai komitmen terhadap perusahaan tersebut, dan bermaksud meneruskan pembelian dimasa mendatang. Terjadinya loyalitas pada konsumen disebabkan oleh adanya pengaruh kepuasan/ketidakpuasan dengan perusahaan tersebut, yang terakumulasi secara terus-menerus disamping adanya presepsi tentang kualitas produk.

Oleh karena itu, pembentukan citra yang ada di dalam benak konsumen terhadap suatu perusahaan khususnya koperasi dapat dilakukan melalui pelaksanaan nilai dan prinsip koperasi secara baik dan benar. Selain itu tidak kalah pentingnya adalah memberikan kepuasan pada para anggota koperasi pada saat melakukan transaksi (transaksi anggota koperasi).

1. Nilai dan prinsip koperasi

Nilai koperasi adalah nilai kesamaan, kekeluargaan, mandiri, peduli terhadap sesama dan kemandirian salah satunya. Koperasi Indonesia berangkat dari nilai koletivisme yang tercermin dengan budaya gotong royong. Nilai yang mendasari kegiatan koperasi yang dipakai pada penelitian ini berupa kekeluargaan dan bertanggung jawab Sedangkan nilai yang diyakini anggota koperasi yang dipakai pada penelitian ini berupa kejujuran dan kepedulian terhadap orang lain.

Prinsip koperasi adalah garis-garis penuntun yang digunakan oleh koperasi untuk melaksanakan nilai-nilai tersebut dalam praktik. Prinsip koperasi ini menjadi sumber inspirasi dan menjiwai secara keseluruhan 
organisasi dan kegiatan usaha koperasi sesuai dengan maksud dan tujuan pendiriannya. Pada penelitian ini mempergunakan prinsip koperasi berupa keanggotaan koperasi bersifat sukarela dan terbuka serta koperasi melayani anggotanya secara prima dan memperkuat Gerakan Koperasi dengan bekerja sama melalui jaringan kegiatan pada tingkat lokal, nasional, regional, dan internasional.

2. Transaksi anggota

Transaksi anggota dilakukan melalui sistem, prosedur dan pelayanan yang baik akan mampu meningkatkan loyalitas anggota pada KSP Jasa di Kabupaten Kendal. Sistem merupakan suatu jaringan transaksi yang dibuat menurut pola yang terpadu untuk melaksanakan kegiatan pokok organisasi dalam hal ini koperasi. Pada KSP Jasa diterapkan sistem transaksi yang cepat dan tepat dibantu pemakaian komputer.

Prosedur adalah suatu urutan kegiatan klerikal, biasanya melibatkan beberapa orang dalam satu departemen atau lebih, yang dibuat untuk menjamin penanganan secara seragam transaksi organisasi yang terjadi berulang-ulang. Pada KSP Jasa di Kabupaten dibuat prosedur yang mudah dan tidak berbelit-belit.

Terakhir berkaitan dengan pelayanan. Pelayanan merupakan faktor ketiga dari transaksi anggota yang sangat penting bagi KSP Jasa di Kabupaten Kendal untuk dapat memberikan kepuasan kepada para anggotanya. Selain itu pelayanan merupakan suatu cara agar anggota tertarik terhadap kinerja suatu koperasi. Kualitas pelayanan yang lebih baik dapat untuk mempertahankan loyalitas anggota koperasi.

\section{Loyalitas}

Dick dan Basu (1994) menyatakan bahwa loyalitas, khususnya terhadap merek adalah: (1) respon kepribadian (yaitu pembelian), (2) yang bersifat bias (non Random), (3) terungkap secara terus-menerus, (4) oleh unit pengambilan keputusan, (5) dengan memperhatikan satu atau beberapa merek alternatif dari 
sejumlah merek sejenis, dan (6) merupakan fungsi proses psikologis (pengambilan keputusan, evaluatif).

Federico (2003) mengatakan loyalitas merek adalah kondisi dimana konsumen mempunyai sifat positif terhadap sebuah perusahaan, mempunyai komitmen terhadap perusahaan tersebut, dan bermaksud meneruskan pembelian dimasa mendatang. Terjadinya loyalitas pada konsumen disebabkan oleh adanya pengaruh kepuasan/ketidakpuasan dengan perusahaan tersebut, yang terakumulasi secara terus-menerus disamping adanya presepsi tentang kualitas produk.

Aviliani (1997) mengatakan loyalitas merek pasti ditujukkan pada objek tertentu. Objek yang dimaksud adalah merek atau atribut lain yang melekat pada produk. Merek dianggap lebih lazim dan lebih banyak menjadi objek loyal karena dianggap sebagai identitas produk atau perusahaan yang lebih mudah dikenali oleh pelanggan. Jika seorang pelanggan menggunakan atribut lain sebagai objek loyal, pada akhirnya juga akan dikaitkan dengan merek favoritnya.

Dewasa ini loyalitas terhadap suatu merek semakin menurun. Hal ini disebabkan oleh beberapa faktor (Loudan dan Albert, 1993) yaitu :

a. Iklan yang semakin gencar, didukung oleh media massa yang semakin canggih.

b. Kesamaan bentuk dan isi produk.

c. Persaingan harga yang semakin tajam.

d. Taktik-taktik penjualan seperti kupon maupun potongan harga yang dapat mendorong konsumen untuk membeli.

e. Kecenderungan perilaku yang berubah-ubah pada perilaku pembelian.

f. Bertambahnya produk-produk baru yang bersaing.

Ada beberapa faktor yang dapat menjelaskan loyalitas merek. Faktorfaktor tersebut menurut Loudan dan Albert (1993) adalah sebagai berikut :

a: Perilaku kesetiaan merek seorang opinion leader mempengaruhi perilaku anggota pada kelompok tersebut.

b. Beberapa karakteristik konsumen berhubungan dengan loyalitas toko, dimana sebaliknya loyalitas toko berhubungan dengan loyalitas merek. 
c. Loyalitas merek secara positif berhubungan dengan perceived risk dan variabel struktur pasar seperti luas distribusi dan market share dari merek yang dominan, tetapi berhubungan timbal balik dengan jumlah toko dimana konsumen membeli.

Perilaku pembelian ulang selain disebabkan oleh kepuasan konsumen dan loyalitas toko juga dapat dipengaruhi oleh usaha-usaha pemasaran. Tujuan utama dari strategi pemasaran adalah meningkatkan market share yang konsisten dari konsumen yang loyal.

Strategi pemasaran yang dapat dilakukan untuk meningkatkan loyalitas konsumen terhadap merek (Loudan dan Albert (1993), antara lain adalah sebagai berikut :
a. Potongan harga, kupon (hadiah).
b. Servis purna jual.
c. Iklan yang gencar dan menarik.
d. Kemasan produk yang menarik.
e. Menambah persepsi dan sikp konsumen.
f. Merubah isi produk.

Konsumen sebenarnya sangat peka terhadap kegiatan pasar, khususnya potongan harga. Dalam pasar di mana terdapat banyak alternatif merek, kegiatan harga, tersedia produk substitusi, loyalitas merek cenderung menurun. Loyalitas merek bukanlah merupakan konsep yang mudah. Terdapat pendekatan yang berbeda pada definisi dan pengukuran pada proses informasi maka terdapat pula perbedaan pandangan terhadap definisi dan pengukuran loyalitas merek.

Menurut para ahli, loyalitas merek dapat diukur melalui berbagai macam cara (Kotler dan Armstrong, 1996), antara lain :

a. Konsumen dianggap loyal jika konsumen tersebut melakukan tiga kali pembelian secara berturut-turut pada merek yang sama.

b. Loyalitas merek diukur dengan proporsi dari total pembelian dimana konsumen setia pada merek yang sering dibeli.

c. Loyalitas merek diukur dari sikap terhadap merek.

d. Loyalitas merek diukur dari tingkat keterlibatan konsumen. 
Kerangka pemikiran dalam penelitian ini adalah sebagai berikut :

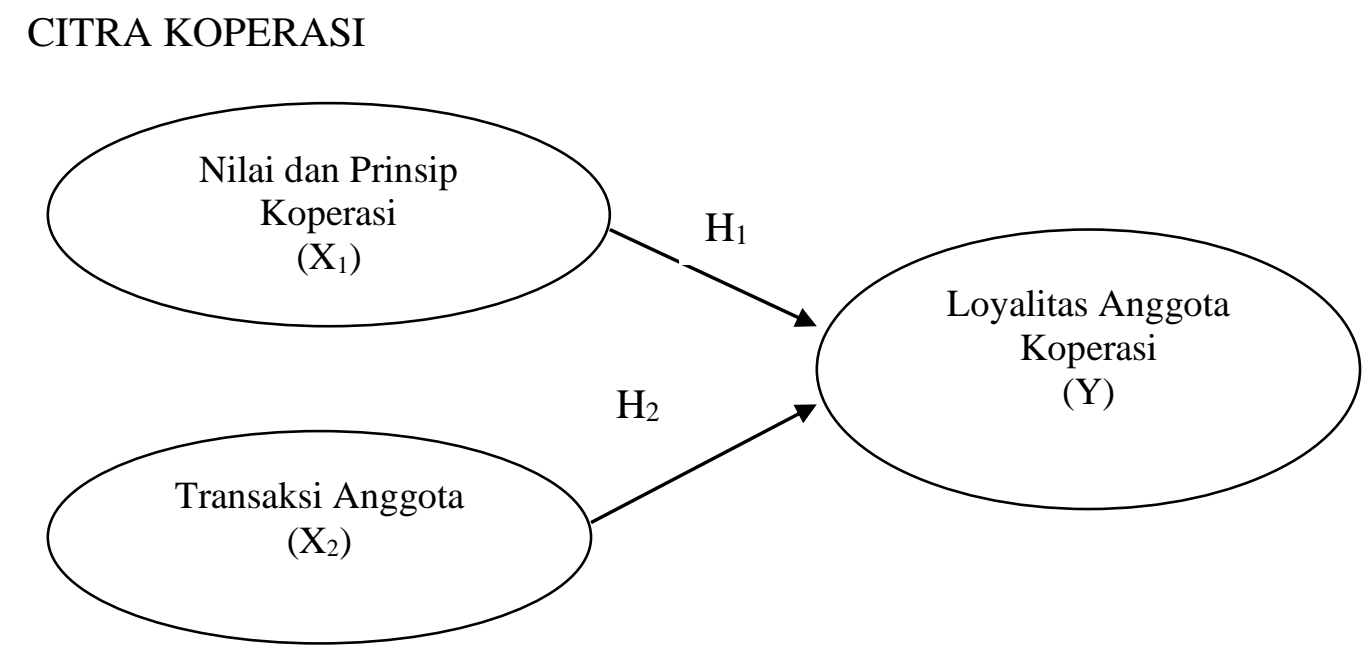

\section{Metodologi}

Populasi penelitian ini adalah seluruh anggota koperasi yang aktif dalam kegiatan perkoperasian yang diselenggarakan oleh KSP Jasa di Kabupaten Kendal. Dalam penelitian ini ditetapkan sampel sebesar 100 orang dari populasi sebanyak 3234 orang. Sampel diperoleh dengan menggunakan rumus Slovin. Untuk mendapatkan data digunakan kuesioner dan juga wawancara pada responden.

Seperti terlihat pada kerangka pemikiran dalam penelitian ini variabel bebas terdiri dari dua yaitu nilai dan prinsip koperasi $\left(\mathrm{X}_{1}\right)$ dan transaksi anggota $\left(\mathrm{X}_{2}\right)$, sedang yang menjadi variabel terikat adalah loyalitas anggota koperasi (Y).

Pengolahan data digunakan metode analisis regresi berganda, koefisien determinasi serta digunakan uji $\mathrm{t}$ dan uji $\mathrm{F}$. Dalam melakukan perhitungan perhitungan digunakan program SPSS. 


\section{Pembahasan}

Diskripsi responden dalam penelitian ini sebagai berikut :

1. Jenis Kelamin
a. Laki-laki
: 51 orang
b. Perempuan
: 49 orang
Jumlah
: 100 orang

2. Umur
a. Kurang dari 20 tahun
: 8 orang
b. 20 tahun -30 tahun
: 22 orang
c. 30 tahun -40 tahun
: 40 orang
d. Lebih dari 40 tahun
: 30 orang
Jumlah
: 100 orang

2. Pendidikan
a. SD dan sederajad
: 7 orang
b. SLTP dan sederajad
: 22 orang
c. SMU dan sederajad
: 41 orang
d. Diploma/Perguruan Tinggi
: 30 orang
Jumlah
: 100 orang

3. Pendapat Kotor per bulan
a. Kurang dari Rp. 2.000.000,-
: 11 orang
b. Rp. 2.000.000,- - Rp. 2.999.999,-
: 24 orang
c. Rp. 3.000.000,- - Rp. 3.999.999,-
: 50 orang
d. Lebih dari Rp. 4.000.000,-
: 15 orang
Jumlah
: 100 orang

Dari deskripsi di atas terlihat bahwa responden sangat beragam baik dilihat dari segi umur, pendidikan maupun dari segi pendapatan.

Berdasarkan perhitungan dengan menggunakan SPSS diperoleh hasil hasil sebagai berikut : 
Tabel 4.1

Hasil Analisis Regresi Berganda

\begin{tabular}{lrrrrrrrr}
\hline & \multicolumn{2}{c}{$\begin{array}{l}\text { Unstandardize } \\
\text { d Coefficients }\end{array}$} & \multicolumn{2}{c}{$\begin{array}{c}\text { Standardized } \\
\text { Coefficients }\end{array}$} & & \multicolumn{3}{c}{ Collinerity Statistics } \\
\cline { 2 - 9 } & $\mathrm{B}$ & $\begin{array}{c}\text { Std. } \\
\text { Error }\end{array}$ & \multicolumn{1}{c}{ Beta } & $\mathrm{T}$ & Sig & Tolerance & VIF \\
\hline 1 (Constant) & 5.113. & .124 & & & & & \\
Nilai dan Prinsip & 924 & .002 & .926 & 4.6369 .82 & .001 & .000 & .177 & 7.1267 \\
Transaksi & .891 & .001 & & .892 & 18.132 & .000 & .186 & .138 \\
\hline
\end{tabular}

a. Dependent Variable : Loyalitas Anggota

Sumber : Data primer yang diolah dengan SPSS

Berdasarkan tabel 4.1 tersebut dapat diketahui persamaan regresinya yaitu :

$$
Y=5,113+0,926 X_{1}+0,892 X_{2}
$$

Dimana :

$$
\begin{array}{ll}
\mathrm{Y} & : \text { Loyalitas Anggota } \\
\alpha & : \text { Konstanta } \\
\beta_{1}, \beta_{2} & : \text { Koefisien regresi variabel bebas } \\
\mathrm{X}_{1} & : \text { Nilai dan Prinsip Koperasi } \\
\mathrm{X}_{2} & : \text { Transaksi Anggota }
\end{array}
$$

Dari hasil regresi tersebut, maka diketahui nilai konstanta $(\alpha)=5,113$, nilai koefisien regresi variabel bebas yaitu citra koperasi berupa nilai dan prinsip koperasi $\left(X_{1}\right)=0,926$ dan transaksi anggota $\left(X_{2}\right)=0,892$.

Uji t dan F test seperti di bawah ini :

T-test ini bertujuan untuk menguji hipotesis $\mathrm{H}_{1}$ dan $\mathrm{H}_{2}$. Hasil uji ini pada output SPSS dapat dilihat pada tabel Coefficient ${ }^{\text {a }}$ seperti terlihat pada tabel 4.2 di bawah ini. 
Tabel 4.2

Hasil Uji Hipotesis Parsial dengan T-test

\begin{tabular}{lrrrrrrr}
\hline & \multicolumn{2}{c}{$\begin{array}{c}\text { Unstandardized } \\
\text { Coefficients }\end{array}$} & \multicolumn{2}{c}{$\begin{array}{c}\text { Standardized } \\
\text { Coefficients }\end{array}$} & \multicolumn{3}{c}{ Collinerity Statistics } \\
\cline { 2 - 8 } & \multicolumn{1}{c}{ B } & Std. Error & \multicolumn{1}{c}{ Beta } & T & Sig & Tolerance & VIF \\
\hline 1 (Constant) & 5.113 & .124 & & 4.636 & .001 & & \\
Nilai dan Prinsip & .924 & .002 & .926 & 9.821 & .000 & .177 & 7.126 \\
Transaksi & .891 & .001 & .892 & 8.132 & .000 & .186 & 7.138 \\
\hline
\end{tabular}

a. Dependent Variable : Loyalitas Anggota

Sumber : Data primer yang diolah dengan SPSS

Dengan mempergunakan Level of Significant $\alpha=5 \%$ pada two-tailed tabel, dengan $\mathrm{n}=100$ dan dan df-k $=98$, diperoleh nilai $\mathrm{T}_{\text {-tabel }}=1,984$.

Hasil Uji model dengan F-test ini pada output SPSS dapat dilihat pada tabel ANOVA berikut ini. Dengan Level of Significant $\alpha=5 \%$, df1 $=2$ dan df 2 $=97$, diperoleh nilai $\mathrm{F}_{\text {-tabel }}=19,50$. Sehingga hasil $\mathrm{F}$-test menunjukkan bahwa model regresi di atas dapat dipakai karena :

a. Nilai p-value $0,00<$ level of significant yang ditentukan 0,05

b. $\quad$ Nilai F- hitung $=67,517>$ F- tabel $=19,50$.

Tabel 4.3

Hasil Uji Hipotesis Simultan Dengan F-test

ANOVA $^{\mathrm{b}}$

\begin{tabular}{|c|c|c|c|c|c|c|}
\hline \multicolumn{2}{|c|}{ Model } & $\begin{array}{l}\text { Sum of } \\
\text { Squares }\end{array}$ & df & Mean Square & $\mathrm{F}$ & Sig. \\
\hline \multirow[t]{3}{*}{1} & Regression & 136.214 & 2 & 27.166 & 67.517 & $.000^{a}$ \\
\hline & Residual & 1.553 & 97 & .548 & & \\
\hline & Total & 137.767 & 99 & & & \\
\hline
\end{tabular}

a. Predictors: (Constant), Nilai dan Prinsip, Transaksi

b. Dependent Variable: Loyalitas Anggota

Sumber : Data primer yang diolah dengan SPSS 


\section{Analisis Koefisien Determinasi $\left(\mathrm{R}^{2}\right)$}

Hasil output SPSS untuk analisis koefisien determinasi $\left(\mathrm{R}^{2}\right)$ dapat dilihat pada Tabel 4.3 di bawah ini.

Tabel 4.3

Hasil Analisis Koefisien Determinasi ( $\mathrm{R}^{2}$ )

Model Summary ${ }^{\text {b }}$

\begin{tabular}{|l|r|r|r|r|r|}
\hline Model & $\mathrm{R}$ & $\mathrm{R}$ Square & $\begin{array}{c}\text { Adjusted } \\
\text { R Square }\end{array}$ & $\begin{array}{r}\text { Std. Error of } \\
\text { the Estimate }\end{array}$ & $\begin{array}{c}\text { Durbin- } \\
\text { Watson }\end{array}$ \\
\hline 1 & $.786^{\mathrm{a}}$ & .785 & .780 & .744 & 1.723 \\
\hline
\end{tabular}

a. Predictors: (Constant), Nilai dan Prinsip, Transaksi

b. Dependent Variable: Loyalitas Anggota

Sumber : Data Primer yang dioleh dengan SPSS 16.0 for Windows

Berdasarkan Tabel 4.3 di atas besarnya koefisien determinasi atau adjusted $\mathrm{R}^{2}$ sebesar 0,780 atau 78,0 persen.

Dari hasil perhitungan SPSS di atas maka :

1. Pengaruh citra koperasi berupa nilai dan prinsip koperasi terhadap loyalitas anggota koperasi pada KSP Jasa di Kabupaten Kendal.

Koefisien variabel nilai dan prinsip koperasi $\left(X_{1}\right)=0,926$ dan bertanda positif. Artinya apabila terdapat peningkatan nilai tanggapan anggota pada variabel nilai dan prinsip $\left(\mathrm{X}_{1}\right)$ sebesar satu satuan sementara variabel transaksi anggota tetap maka loyalitas anggota koperasi (Y) pada KSP Jasa di Kabupaten Kendal mengalami peningkatan sebesar 0,926.

Dari uji t dapat dilihat bahwa nilai signifikansinya 0,000 lebih kecil dari 0,05, ini berarti bahwa benar nilai dan prinsip koperasi berpengaruh terhadap loyalitas anggota koperasi pada KSP Jasa di Kabupaten Kendal.

2. Pengaruh citra koperasi berupa transaksi anggota terhadap loyalitas anggota koperasi pada KSP Jasa di Kabupaten Kendal.

Koefisien variabel transaksi anggota $\left(\mathrm{X}_{2}\right)=0,892$ dan bertanda positif. Artinya apabila terdapat peningkatan nilai tanggapan anggota pada variabel transaksi anggota $\left(\mathrm{X}_{2}\right)$ sebesar satu satuan sementara variabel nilai dan 
prinsip $\left(\mathrm{X}_{1}\right)$ tetap maka loyalitas anggota koperasi (Y) pada KSP Jasa di Kabupaten Kendal mengalami peningkatan sebesar 0,892.

Dari uji t dapat dilihat bahwa nilai signifikansinya 0,000 lebih kecil dari 0,05, ini berarti bahwa benar transaksi koperasi berpengaruh terhadap loyalitas anggota koperasi pada KSP Jasa di Kabupaten Kendal.

Hasil uji kelayakan model dengan $\mathrm{F}$ test didapat $\mathrm{F}$ hitung sebesar 67,517 dengan tingkat signifikansi 0,000 (lebih kecil dari 0,05), dengan demikian dapat disimpulkan bahwa metode dalam penelitian ini merupakan model yang fit.

Koefisien Determinasi pada intinya adalah mengukur seberapa besar atau seberapa jauh kemampuan model pada variabel bebas $(\mathrm{X})$ dalam menerangkan variabel terikat (Y). Dari tabel di atas angka koefisien Determinasi (Adjusted $R$ Square)

Sebesar 0,780. Hal ini berarti bahwa variabel nilai dan dan prinsip dan transaksi mempunyai pengaruh sebesar $78 \%$ secara bersama sama dapat menjelaskan variabel loyalitas anggota koperasi. Sedang sisanya sebesar 0,22 atau $22 \%$ dijelaskan oleh variabel lain yang mempengaruhi loyalitas anggota koperasi.

\section{Kesimpulan}

Berikut ini adalah kesimpulan dari hasil penelitian yang telah dilakukan yaitu :

1. Citra koperasi berupa nilai dan prinsip koperasi berpengaruh terhadap loyalitas anggota koperasi pada KSP Jasa di Kabupaten Kendal.

2. Citra koperasi berupa transaksi anggota berpengaruh terhadap loyalitas anggota koperasi pada KSP Jasa di Kabupaten Kendal. 


\section{DAFTAR PUSTAKA}

Aviliani, Elu Wilfridus, 1997, Membangun Kepuasan Pelanggan Melalui Kualitas Pelayanan, Usahawan, Jakarta

Dharmesta, Basu, 1999, Loyalitas Pelanggan Sebuah Kajian Konseptual Sebagai Panduan Bagi Peneliti; Jurnal Ekonomi dan Bisnis Indonesia vol.14 N.3.73-88.

Federico Rajola, 2003, Customer Relationship Management-Organizational and Technological Perspectives, Springer, New York

Gulo, W., 2000, Metodologi Penelitian, Penerbit Grasindo, Jakarta

Istijanto, 2005, Aplikasi Praktis Riset Pemasaran, Penerbit PT. Gramedia Pustaka Utama, Jakarta

Kartajaya, Hermawan, 1996, Marketing Plus 2000 Siasat Memenangkan Persaingan Global. PT. Gramedia Pustaka Utama, Jakarta.

Keputusan Menteri Koperasi dan Usaha Kecil dan Menengah Nomor: 96/Kep/M.KUKM/IX/2004 tentang Pedoman Standar Operasional Manajemen (SOM)

Kotler, Phillip, 1997, Manajemen Pemasaran (terj), Edisi Ketiga, Jilid I dan II, Penerbit Erlangga, Jakarta.

Kotler, Philip dan Armstrong, Garry, 1996, Priciple of Marketing, Ninth Edition, Prentice Hall, Inc. Upper Saddle River, New Jersey.

Loudan, David L. dan Albert J. Della Bitta, 1993, Consumer Behavior :Concept and Application, Fourth Edition, McGrow Hill Book Co., Singapore.

Mowen. H. 2002. Perilaku Konsumen. Jilid I. Penerbit. Andi. Yogyakarta.

Nitisemito, Alex., 1991, Manajemen Pemasaran, Edisi Kedua, Cetakan keempat, Penerbit Ghalia, Jakarta.

Nugroho, Bhuana Agung, 2005, Strategi Jitu Memilih Metode Statistik Penelitian dengan SPSS, Penerbit CV. Andi Offset, Yogyakarta.

Poerwadarminto, 1992, Memahami Perilaku Konsumen, Edisi Ketiga, Cetakan Kedua, Penerbit Cahaya, Yogyakarta. 
Sarwono, Jonathan, 2010, Pintar Menulis Karya Ilmiah-Kunci Sukses dalam Menulis Ilmiah, Penerbit, CV. Andi Offset, Yogyakarta

Situmorang, Syafizal et al., 2010, Analisis Data : untuk Riset Manajemen dan Bisnis, USU Press, Medan

Suharsimi Arikunto, 1992, "Prosedur Penelitian Suatu Pendekatan Praktek", Edisi Pertama, Penerbit PT. Rineka Cipta, Bandung

Sugiyono, 2003, Metode Penelitian Bisnis, Alfabeta, Bandung.

Swastha, Basu, 1996, Manajemen Pemasaran Modern, Edisi kedua, Cetakan keempat, Liberty, Yogyakarta.

Tjiptono, 2001, Pemasaran Yang Efektif, Edisi ke-1, LP3ES, Jakarta

Umar, Husein, 2005, Riset Pemasaran dan Perilaku Konsumen, Cetakan keempat, Penerbit Gramedia Pustaka Utama, Jakarta

Undang-Undang Nomor 25 Tahun 1992 tentang Pokok-Pokok Perkoperasian

Undang-Undang No. 37 Tahun 2004 tentang Kepailitan dan Penundaan Kewajiban Pembayaran Utang 